\section{Dawlish Warren}

\section{from a Correspondent}

DAwLISH WARREN at the mouth of the River Exe in South Devon is one of several places on the coast of Britain which is being seriously eroded. The Warren is a structure which extends from the western shore and runs eastwards across the mouth of the Exe, and it consists of two ridges of low sand hills, known as the Inner and Outer Warrens which are separated by a dry low-lying area called the Greenland Lake. Periodically, however, the line of the Outer or seaward Warren is broken, such occasions occurring when a high spring tide coincides with a south-easterly gale. Since 1787 much of the Outer Warren has been removed by erosion. A considerable area formerly covered by the Outer Warren is still, however, represented by a great expanse of sandbanks which extend for some $300 \mathrm{~m}$ $(1,000 \mathrm{ft}$.) to the seaward of the present-day high-water level. These sandbanks link to the east with an even more extensive bank known as the Pole Sand. Similarly, on the landward side of the Warren the course of

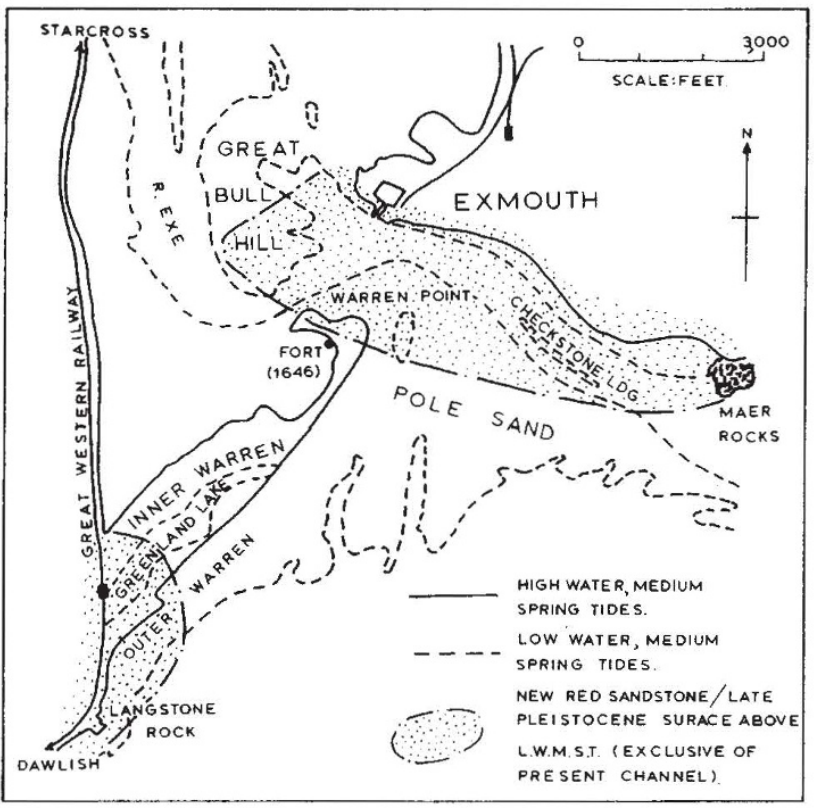

The extent of Dawlish Warren and the area of New Red Sandstone breccia and Late Pleistocene gravels above the level of low water of medium spring tides.

the River Exe is restricted by banks of mud, sand and gravel, the largest of which is the Great Bull Hill. There have been several theories as to the sedimentary history of the Warren. E. M. Durrance of the Department of Geology, University of Exeter, has done some detailed seismic studies on the thickness of recent sediments infilling the buried channel of the Exe on both the Warren and the intertidal banks. The results of the survey indicate that Dawlish Warren is a far more complex structure than has previously been thought, and they provide clues both to its origin and to its future history. A platform of New Red Sandstone breccia slopes from its outcrop at low-water level in the south-west to a depth of $-23 \mathrm{~m}(-75 \mathrm{ft})$ in the north-east, and is deeply cut down to $-45 \mathrm{~m}(-150 \mathrm{ft})$ by a number of channels running north-west to southeast across it. These channels have been later infilled with Late Pleistocene (Middle Weichselian) gravels and re-channelled to depths about $-30 \mathrm{~m}(-100 \mathrm{ft})$. The surface of the subsequent composite New Red Sandstone breccia and Late Pleistocene gravel was then inundated by the Flandrian transgression and was submerged to various depths. In the west, near Langstone Rock, and in the east, in an area extending from Warren Point to Exmouth, this surface is at a level above low water of ordinary spring tides and it appears to have acted as a trap for a coarse pebble layer soon after its submerging. On rising above highwater level, possibly as a result of deposition during periods of high flood water, this pebble layer appears in turn to have acted as a trap for wind-blown sand. Durrance thinks, therefore, that the growth of the Warren began from these two nuclei simply by the accretion of pebbles and wind-blown sand, with possibly very little net lateral movement of sediment taking place.

Between the two high level areas of Langstone Rock and Warren Point, the intervening New Red Sandstone -Late Pleistocene surface is at a depth, exclusive of channels, of $-14 \mathrm{~m}(-45 \mathrm{ft})$. During historical times this area seems to have been occupied by the main channel of the River Exe. Exmouth fort, dated 1646 and marked by the Ordnance Survey as being situated on the south-west shore of Warren Point, would have been in an ideal position for the command of a channel opening to the west of the present mouth of the Exe.

The present course of the Exe between Warren Point and Exmouth occupied a channel cut through the New Red Sandstone-Late Pleistocene surface, both divisions outcropping above low-water level of ordinary spring tides in the Pole Sand and Checkstone Ledge, and covered by only a thin veneer of dry wind-blown sand on the Exmouth shore. This suggests to Dr Durrance that the present channel, with an average depth of only $4 \mathrm{~m}$ (12 ft) at low water of ordinary spring tides, occupies an unstable position and of very recent origin. This agrees with $R$. Polwhele's observation in 1797 (The History of Devonshire).

\section{Well-bred Animals}

The Laboratory Animals Centre at Carshalton, Surrey, has as healthy a set of animals as anybody could hope to find. The centre has a record to be proud of; not only does it have the largest collection of inbred strains in the world, but it was also the first centre of its kind to be established.

The twenty or so species of animals at present held in the centre include rats, mice, cats, Libyan gerbils, Chinese hamsters, sheep and goats. These are invaluable in experiments conducted both in Great Britain and abroad (Nature, 218, 519). Within the foreseeable future it is expected that reptiles, amphibia and fish will be added to the list as their experimental use grows.

The concept of having to use stray animals in experiments is now just about as obsolete as the earlier practice of stealing cadavers from graveyards for anatomical investigations. As Mr J. Bleby, director of the centre, pointed out, it is mainly the hospitals and universities that continue to use stray animals for their experiments, claiming that they cannot afford 
to buy animals from the centre, which charges $£ 15$ for a cat. In the long run, however, Mr Bleby maintains that carefully bred, often vaccinated and genetically defined animals obtained from the centre are more economical as fewer need to be used.

About 90 per cent of all animals used in experiments in Britain come from commercial breeders who are under the direct control of the Medical Research Council. This accredited breeders scheme was started by the Laboratory Animals Centre in 1950 to boost large-scale production of the animals, and is voluntary. But the demand for specialized strains of animals has become so great that the breeders alone cannot cope and the centre now maintains a number of strains from which breeding nuclei are supplied. Together with the specific pathogen free (SPF) and germ-free animals, these breeding nuclei have become a major feature of the centre.

SPF animals are, as the name suggests, without disease, but they still have a normal gut flora. Germ. free animals, on the other hand, are completely without bacteria and the technical difficulties in rearing these animals are considerable. For this reason, the rearing of small germ-free animals at Carshalton is still at the pilot stage under the direction of Dr D. K. Blackmore. These animals will be used to restock the SPF unit should any mishap occur there, such as infection of the animals. They can also be used, however, in specific studies such as determining the synergistic effect of certain bacteria or, as Dr H. B. Stoner at the centre suggested, to find out why some food additives become toxic in the human body; this could either be a result of the action of the gut flora, or part of the normal human metabolism.

Germ-free swine and cattle are also being reared at the Royal Veterinary College, London, with considerable success. Here they are being used by Dr P. C. Trexler and his colleagues to study respiratory diseases; for the production of monospecific antisera against viruses; and for investigating the role of the normal bacteria in the economy of the animal. Even more striking is the news that a human child was born in December under germ-free conditions. The reason for this strange delivery was given by Mrs M. Tuffrey at the Institute of Child Health and is that the child had a one in four chance of being born with a specific defect of the immunological mechanism; the mother had already lost one child as a result of this defect. The child was therefore delivered prematurely by caesarean section in a specially designed isolator at University College Hospital, and was then transported in an isolator to the Institute of Child Health where she was kept in a maintenance isolator for seven days during which time she was fed on sterile canned milk. As it turned out, the results of a number of tests carried out during this time showed that the child was in fact normal, but Mrs Tuffrey said that it could have been kept in isolation for up to one month had the need arisen. She added that as babies usually die as a result of this deficiency at four months, there would have been time for the clinicians to diagnose and try to treat the disease, perhaps by grafting immunocompetent tissue such as the thymus. Mrs Tuffrey suggested that the treatment of patients who are unduly susceptible to infection in a protective environment such as a germ-free isolator would be useful in a number of diseases such as leukaemia, burns and, of course, in helping those transplant patients receiving immunosuppressive treatment. Whether or not gnotobiotics has advanced sufficiently to justify the delivery of a human child under germ-free conditions seems, however, debatable.

\section{Hot Soak for Seeds}

ONE of the best ways to spread plant diseases is through the sale and shipment of seed. In some cases, such as celery leaf rust, only one infected plant in 10,000 is needed to cause an epidemic in the crop. Particularly critical are fungal diseases lodged within the seed where seed dressings cannot reach them. The problem in dealing with these diseases has been to kill the fungus but not the seed.

This type of disease can now be completely eliminated by a process developed at the National Vegetable Research Station (near Warwick) which was on view at last week's Chelsea Flower Show. The treatment is first to soak seed for twenty-four hours in a solution containing 0.2 per cent of the fungicide 'Thiram' at $30^{\circ} \mathrm{C}$. The seed is then dried by driving air through it for several hours. So far this treatment has been found to give complete control in eleven commercially important plant species with infections involving eighteen different seed-borne diseases. The plants, with the number of specific diseases which can be controlled given in parentheses, are: pea (2), celery (1), carrot (2), brassicas (2), beet (3), trefoil (1), flax (1), oats (1), wheat (2), barley (2), lobelia (1); tick-beans have shown 70-80 per cent control. For the many flower seeds which are sensitive to the treatment the concentration of the soak is cut by half.

For the first time this year the principal celery seed company in the United Kingdom is selling 'Thiram' soaked seed. Dr Keyworth, the head of the plant pathology department at the National Vegetable Research Station, points out: "We've now got a method where we can give 100 per cent guarantee that seeds are free from fungal disease and this is the very first time that anyone anywhere can say this"'. This should have sales appeal abroad. The treatment also substantially increases germination rates and this makes it popular with growers. The economic advantage of seedsoaking over controlling a disease in the field is great. A few pence for seed treatment as against $£ 100$ to spray for celery blight in a ten acre field is a comparison which has been quoted.

\section{Disease as a Social Problem}

The Arthritis and Rheumatism Council for Research and the British Rheumatism and Arthritis Association have together compiled a report on the social consequences of arthritis and rheumatism. The most interesting parts of this report are drawn from a more analytical statistical study on arthritis in Britain by the World Health Organization.

It is estimated that some 30 million working days are lost in a year as a result of arthritis, at a cost to the country of $£ 130$ million. Miners, because of the often cramped conditions of their work, have the highest number of lost days-134 days lost/100 men/year. Then come electrical linesmen, lorry driver mates and other jobs connected with lifting heavy loads. At any 